\title{
Micropropagation of Litsea glutinosa (Lour) C.B
}

\author{
Syed Naseer Shah ${ }^{1}$, Amjad M. Husaini ${ }^{2 \star}$ and S. A. Ansari ${ }^{1}$ \\ ${ }^{1}$ Genetics and Plant Propagation Division, Tropical Forest Research Institute, Mandla Road, Jabalpur 482021 , India. \\ ${ }^{2}$ Centre for Plant Biotechnology, Division of Biotechnology, SKUAST-K, Shalimar, Srinagar-191121, J\&K, India.
}

Accepted 9 September, 2013

\begin{abstract}
Litsea glutinosa (Lour) C.B (Hindi: Maida lakri) is a medicinal plant of immense pharmaceutical value. The species is critically endangered due to its indiscriminate collection as raw material for pharmaceutical industry, where it is used for manufacturing drugs for pain, arousing sexual power and in treatment of diarrhea and dysentery etc. An attempt has been made for development of in vitro propagation procedure for the species, involving four steps, namely: culture establishment, shoot multiplication, rooting and hardening. Aseptic cultures were established on Murashige and Skoog (MS) medium supplemented $10.0 \mu \mathrm{M} \mathrm{N}^{6}$-benzyladenine (BA) using nodal segments $(1 \mathrm{~cm})$. Four sets of simple randomized experiment were carried out on MS medium to study the effect of four doses of each $B A, \mathrm{GA}_{3}, \mathrm{IAA},(0,2.5,5.0$ and $10 \mu \mathrm{M})$ and ascorbic acid $(0,284,852$ and $1136 \mu \mathrm{M})$ for in vitro shoot multiplication. MS medium supplemented with $5.0 \mu \mathrm{M}$ BA with $852 \mu \mathrm{M}$ ascorbic acid significantly proved optimum for in vitro shoot multiplication and resulted in 1.05 shoot number explant ${ }^{-1}, 1.72$ node number shoot $^{-1}$ and 1.79 node number explant ${ }^{-1}$ at one month after inoculation. The in vitro multiplied shoots were tested for in vitro root induction on MS culture media containing auxin IBA (Indole-3-butaric acid) treatments $(0,2.5,5.0$ and10.0 $\mu \mathrm{M})$ in simple randomized designs experiment. MS media supplemented with $10.0 \mu \mathrm{M}$ IBA, screened out to be significantly excellent for induction and growth of adventitious roots, resulting in $72.2 \%$ rooting and 0.72 root number explant ${ }^{-1}$ at 30 days after inoculation. The in vitro propagated plants exhibited excellent growth. Therefore, the present study recommends a four step micropropagation procedure for in vitro production of $L$. glutinosa plants on a commercial scale to meet the requirement of pharmaceutical industries and save the species from extinction.
\end{abstract}

Key words: Litsea glutinosa (Lour) C.B, ascorbic acid, nodal segments.

\section{INTRODUCTION}

Litsea glutinosa (Family Lauraceae) is an evergreen tree of medium size, which grows to a height of about $25 \mathrm{~m}$. Found in mixed primary and secondary forest and thickets throughout india and in the outer Himalayas' (Kirtikar and Basu, 1981). L. glutinosa contain photoconstituents like alkaloids, glycosides, flavonoids, saponins, tannins, phenolic compounds etc. The bark of $L$. glutinosa, "is one of the most popular of native drugs", is considered to be capable of relieving pain, arousing sexual power and good for stomach in treatment of diarrohea and dysentery. L. glutinosa is widely used as a demulcent and as an emollient. The phytochemical constituents of bark of L. glutinosa have been shown to possess effective antibacterial and antifungal activity (Hosamath, 2011). This species is critically endangered (Reddy and Reddy 2008). The conventional propagation is hampered due to low seed viability and no rooting of vegetative cuttings (Rabena, 2010).

Thus there is need for alternative in vitro propagation method for large scale multiplication, improvement and conservation of the species. The objective of the study was to develop a procedure for its micropropagation. 


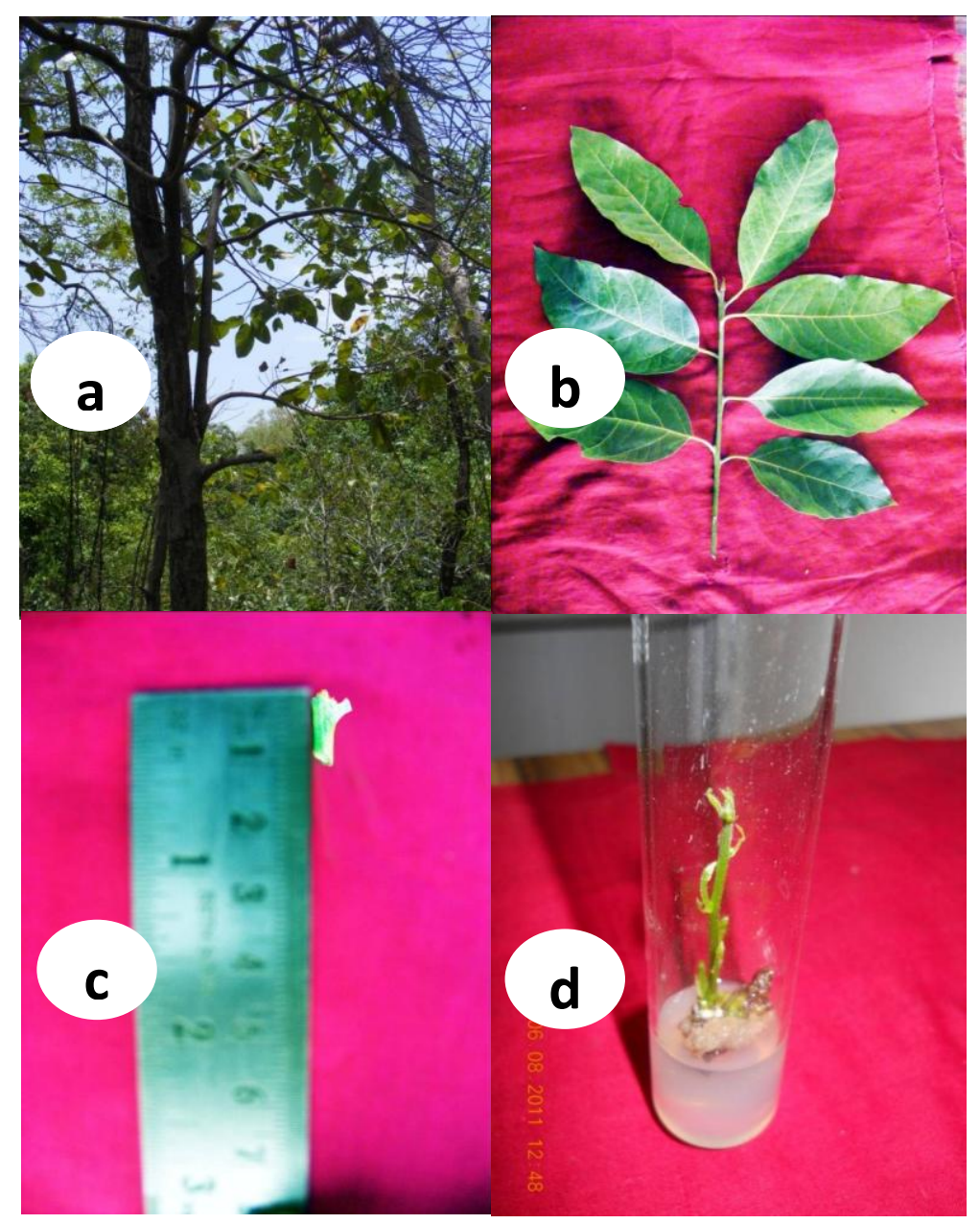

Figure 1. Explant collection, culture establishment and shoot multiplication in Litsea glutinosa, (a) mother plant, (b) a twig, (c) nodal explants, (d) in vitro shoot establishment on MS medium + $10 \mu \mathrm{M}$ BA.

\section{MATERIALS AND METHODS}

The selected (mother) plants (Figure 1a) were used to collect twig (s) (Figure 1b), which were brought in laboratory and washed thoroughly for $15 \mathrm{~min}$ under running water for removing the debris from the surface. The washed twigs were defoliated and cut into nodal explants (approximately 1 to $1.5 \mathrm{~cm}$ long and 0.5 to $0.6 \mathrm{~cm}$ diameter) (Figure 1c). These explants were washed with $2 \%$ Cetrimide ${ }^{\circledR}$ and kept for 10 min with constant vigorous shaking (150 rpm) on an orbital shaker incubator. The explants were rewashed 4 to 5 times with distilled water to remove traces of Cetrimide ${ }^{\circledR}$. The washed explants were sterilized for $5 \mathrm{~min}$ with a composite sterilization treatment comprising $\mathrm{HgCl}_{2}(0.1 \%)$, Bavistin ${ }^{\circledR}(1.0 \%)$ and $\operatorname{Streptomycin}^{\circledR}(0.2 \%)$ in the laminar flow cabinet. Finally, the surface sterilized nodal explants were rinsed 4 to 5 times with sterile distilled water for removal of sterilizing agent under laminar flow cabinet. The nodal segments were inoculated on MS medium (Murashige and Skoog, 1962) supplemented with 10.0 $\mu \mathrm{M}$ BA for culture establishment (Figure 1d).

\section{Shoot multiplication}

Four sets of simple randomized experiment were carried out on MS medium to study the effect of four doses of each BA, GA 3, IAA, $(0$, 2.5, 5.0 and $10 \mu \mathrm{M})$ and ascorbic acid $(0,284,852$ and $1136 \mu \mathrm{M})$ for in vitro shoot multiplication. Shoot number explant ${ }^{-1}$, node number shoot ${ }^{-1}$ and node number explant ${ }^{-1}$ were recorded (Figure 2a-c).

\section{Root induction}

A simple randomized experiment was carried out to study the effect of four doses of IBA $(0,2.5,5.0$ and $10 \mu \mathrm{M})$ on root induction at 30 days after inoculation.

\section{Culture conditions and statistical analysis}

The inorganic salts used for preparation of culture medium were obtained from Qualigens Pvt. Ltd., India and phytohormones and B vitamins from Sigma Chemicals Pvt. Ltd., MS medium was used in all the experiments with $5.0 \mu \mathrm{M}$ BA. India. The medium contained $3 \%(\mathrm{w} / \mathrm{v})$ sucrose, $0.65 \%(\mathrm{w} / \mathrm{v})$ agar (Hi-media chemical Ltd., India). The $\mathrm{pH}$ of the medium was adjusted to 6.0 before autoclaving for $15 \mathrm{~min}$ at $1.06 \mathrm{~kg} \mathrm{~cm}^{-2}\left(121^{\circ} \mathrm{C}\right)$. Explants were cultured in $150 \mathrm{ml}$ culture bottles containing $40 \mathrm{ml}$ semi-solid medium. For in vitro 


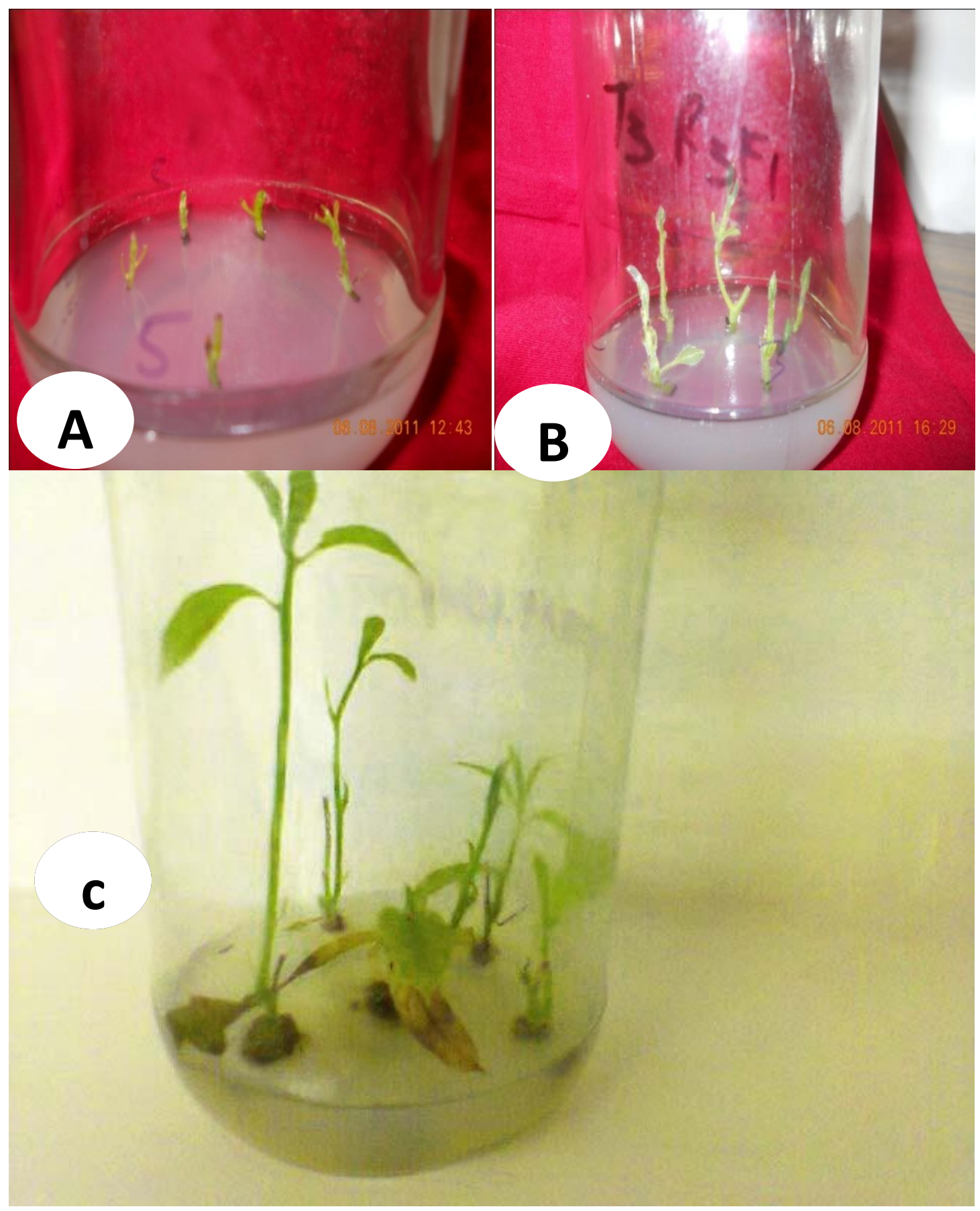

Figure 2. In vitro shoot multiplication in Litsea glutinosa, (a) MS medium supplemented $5 \mu \mathrm{M} B A+5 \mu \mathrm{M}$ IAA, (b) MS medium $5 \mu \mathrm{M} \mathrm{BA}+5 \mu \mathrm{M} \mathrm{GA}$, (c) MS medium $+5 \mu \mathrm{M} B A+825 \mu \mathrm{M}$ ascorbic acid at 30 days after inoculation.

shoot multiplication experiments, the cultures were incubated at 25 $\pm 2^{\circ} \mathrm{C}$ under $16 \mathrm{~h}$ illuminations with fluorescent light $\left(50 \mu \mathrm{Em}^{-2} \mathrm{~s}^{-1}\right)$. The experiments had thee replicates for in vitro shoot multiplication and three replicates for in vitro rooting (Figure 3). Each replicate had 10 propagules. In all five experiments the data were recorded at 30 days after inoculation. The data were subjected to one way (factor) analysis of variance for all the experiments with "F" test for ascertaining level of significance. If the data were found significant at $p \leq 0.05, \mathrm{LSD}_{0.05}$ was computed for comparison of treatment means.

\section{Hardening and transplantation}

The in vitro raised plantlets were removed from rooting medium, washed with distilled water and the plantlets were transferred to 

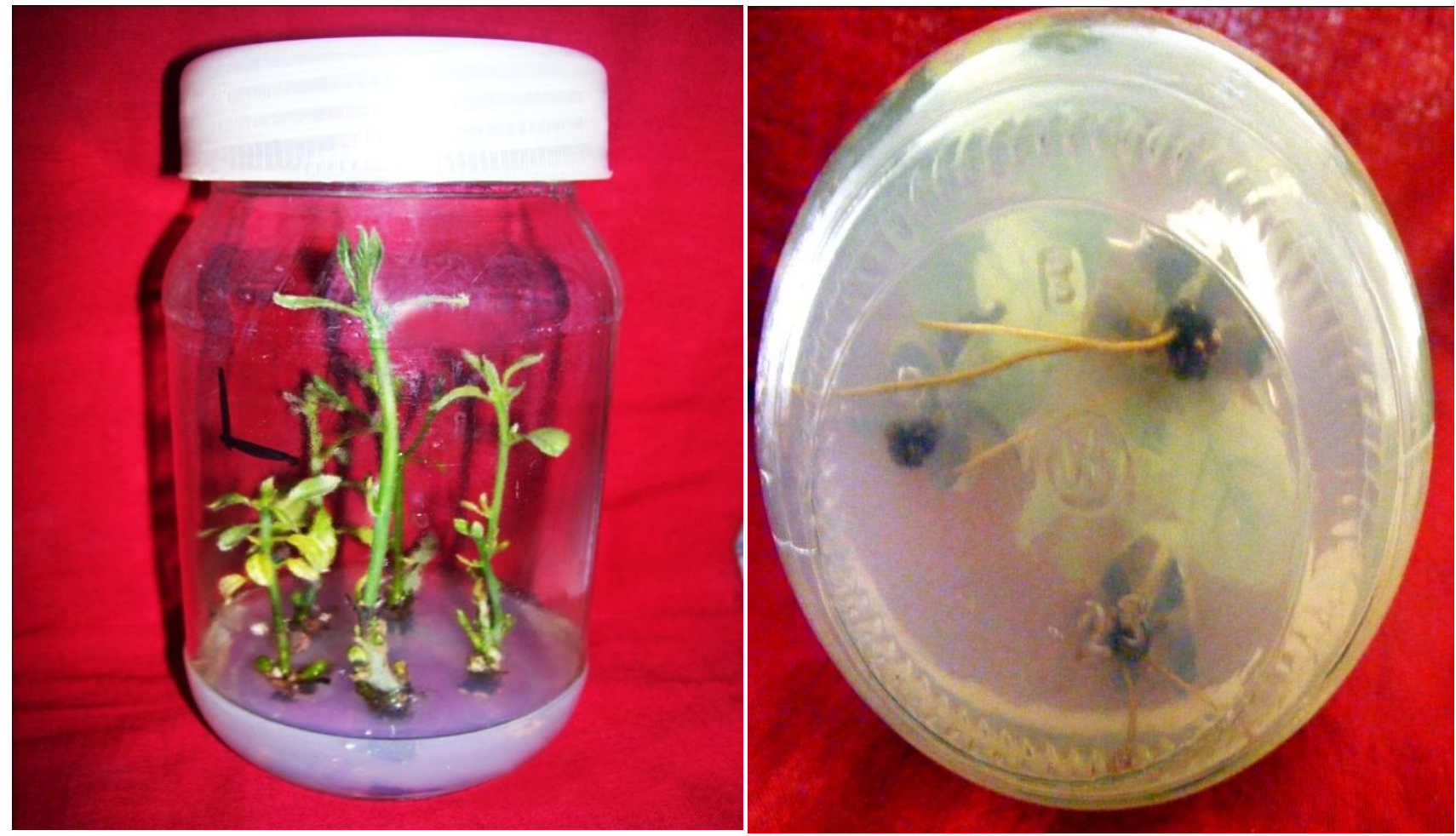

Figure 3. The in vitro adventitious root induction Litsea glutinosa, root formation on semi-solid MS medium with $10 \mu \mathrm{M}$ IBA at 30 days after inoculation.

sand beds in the mistchamber and the plantlets were covered with culture bottles to maintain humidity (Figure 4a).

Subsequently, they were transferred to perforated polythene bags and kept initially in mistchamber for 10 days and finally transferred to natural environmental conditions (Figure 4b).

\section{RESULTS}

\section{In vitro shoot multiplication}

\section{Experiment 1}

Shoot number explant ${ }^{-1}$ : Effect of different doses of BA at 0 to $10 \mu \mathrm{M}$ produced statistically similar value for shoot number explant ${ }^{-1}$ at 30 days after inoculation. The effect of BA was found to be non significant on shoot number explant ${ }^{-1}$ at the stage of sampling (Table 1).

Node number shoot ${ }^{-1}$ : Use of BA significantly influenced node number shoot ${ }^{-1}$ at 30 days after inoculation. $5 \mu \mathrm{M}$ BA enhanced node number shoot ${ }^{-1}$ by $25 \%$ in comparison to the control at the stage of sampling.

Node number explant ${ }^{-1}$ : Various doses of BA significantly influenced node number explant ${ }^{-1}$ at 30 days after inoculation. 5.0 BA $\mu \mathrm{M}$ significantly enhanced node number explant ${ }^{-1}$ by $27 \%$ in comparison to the control at the stage of sampling.

\section{Experiment 2}

Shoot number explant ${ }^{-1}$ : Effect of different doses of IAA significantly influenced shoot number explant ${ }^{-1}$ at 30 days after inoculation. $5 \mu \mathrm{M}$ IAA significantly enhanced shoot number explant ${ }^{-1}$ by $22 \%$ in comparison to the control at the stage of sampling (Table 2).

Node number shoot ${ }^{-1}$ : Use of IAA significantly influenced node number shoot ${ }^{-1}$ at 30 days after inoculation. $5.0 \mu \mathrm{M}$ IAA significantly enhanced node number shoot ${ }^{-1}$ by $33 \%$ in comparison to the control at the stage of sampling.

Node number explant ${ }^{-1}$ : Various doses of IAA significantly influenced node number explant ${ }^{-1}$ at 30 days after inoculation. 5.0 $\mu \mathrm{M}$ IAA significantly enhanced node number explant ${ }^{-1}$ by $55 \%$ in comparison to the control at the stage of sampling.

\section{Experiment 3}

Shoot number explant ${ }^{-1}$ : Effect of different doses of $\mathrm{GA}_{3}$ significantly influenced shoot number explant ${ }^{-1}$ at 30 days after inoculation. Maximum shoot number explant ${ }^{-1}$ were obtained on $5.0 \mu \mathrm{M} \mathrm{GA}_{3}$ which was significantly higher than shoot number explant ${ }^{-1}$ into other doses of $\mathrm{GA}_{3} 5.0$ 


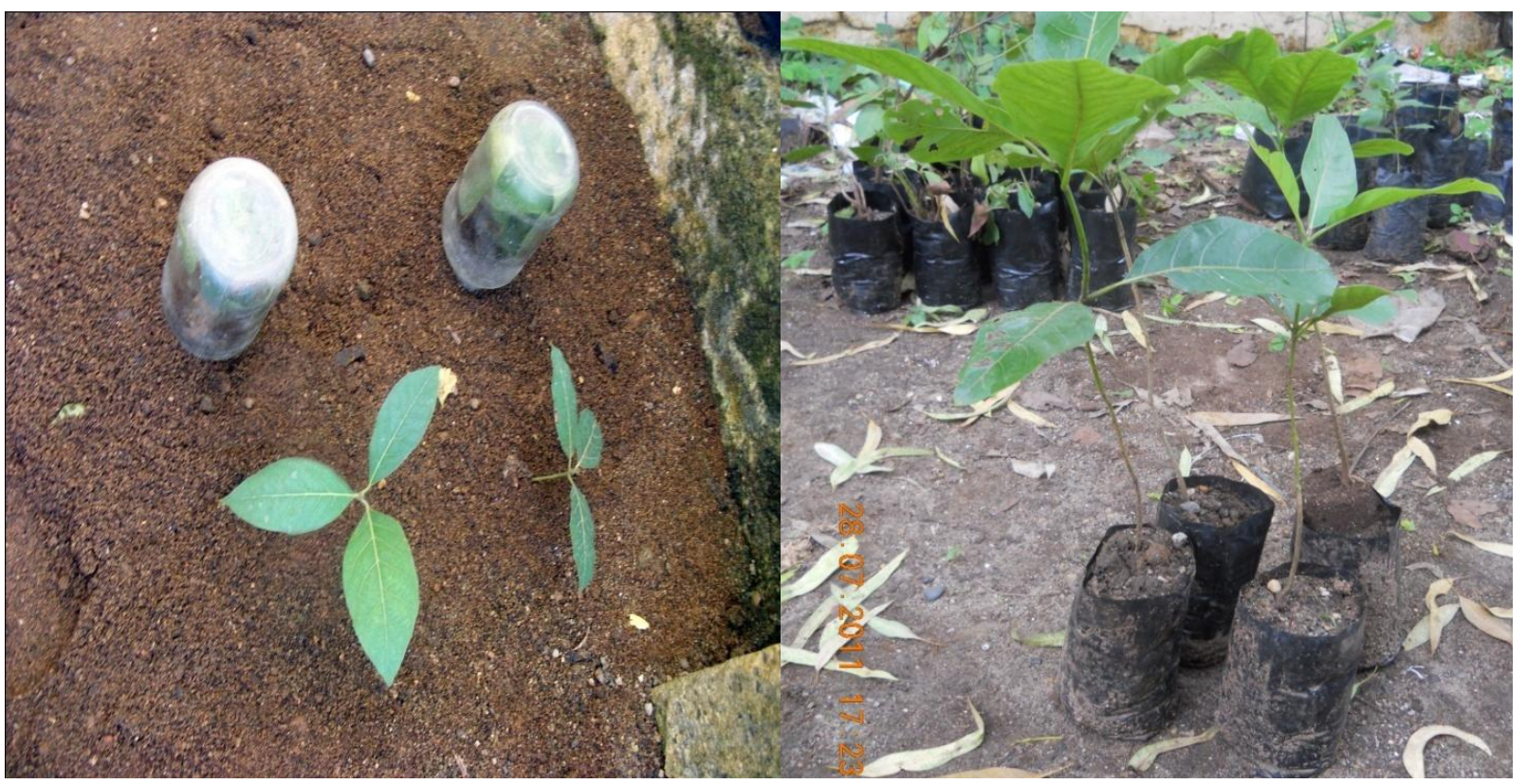

Figure 4. Hardening and acclimatization of the in vitro raised plantlets of Litsea glutinosa, transferred into (a) sand bed covered with culture bottles in mistchamber, (b) growth of plantlets in the open environment.

Table 1. Effect of different doses of BA on shoot number explant ${ }^{-1}$, node number shoot $^{-1}$ and node number explant ${ }^{-1}$ at 30 days after inoculation. MS medium supplemented with uniform dose of $5.0 \mu \mathrm{M}$ BA.

\begin{tabular}{lccc}
\hline $\begin{array}{l}\text { Doses BA } \\
(\mu \mathrm{M})\end{array}$ & $\begin{array}{c}\text { Shoot number } \\
\text { explant }^{-1}\end{array}$ & $\begin{array}{c}\text { Node number } \\
\text { shoot }^{-1}\end{array}$ & $\begin{array}{c}\text { Node number } \\
\text { explant }^{-1}\end{array}$ \\
\hline 0 & 1.0 & 1.0 & 1.0 \\
2.5 & 1.0 & 1.0 & 1.0 \\
5.0 & 1.0 & 1.25 & 1.27 \\
10 & 1.0 & 1.0 & 1.0 \\
$\mathrm{LSD}_{(0.05)}$ & $\mathrm{NS}$ & 0.09 & 0.01 \\
\hline
\end{tabular}

Table 2. Effect of different doses of IAA on shoot number explant ${ }^{-1}$, node number shoot ${ }^{-1}$ and node number explant ${ }^{-1}$ at 30 days after inoculation. MS medium supplemented with uniform dose of $5.0 \mu \mathrm{M}$ BA.

\begin{tabular}{lccc}
\hline $\begin{array}{l}\text { Doses IAA } \\
(\mu \mathrm{M})\end{array}$ & $\begin{array}{c}\text { Shoot number } \\
\text { explant }^{-1}\end{array}$ & $\begin{array}{c}\text { Node number } \\
\text { shoot }^{-1}\end{array}$ & $\begin{array}{c}\text { Node number } \\
\text { explant }^{-1}\end{array}$ \\
\hline 0 & 1.0 & 1.0 & 1.0 \\
2.5 & 1.0 & 1.0 & 1.05 \\
5.0 & 1.22 & 1.31 & 1.55 \\
10 & 1.0 & 1.0 & 1.0 \\
LSD $_{(0.05)}$ & 0.10 & 0.03 & 0.25 \\
\hline
\end{tabular}

$\mu \mathrm{M} \mathrm{GA} \mathrm{A}_{3}$ enhanced shoot number explant ${ }^{-1}$ by $44 \%$ in comparison to the control at the stage of sampling (Table 3).
Node number shoot ${ }^{-1}$ : Effect of different doses of $\mathrm{GA}_{3}$ was found to be non significant at 30 days after inoculation. 5.0 to $10.0 \mu \mathrm{M} \mathrm{GA}_{3}$ produced statistically 
Table 3. Effect of different doses of $\mathrm{GA}_{3}$ on shoot number explant ${ }^{-1}$, node number shoot ${ }^{-1}$ and node number explant ${ }^{-1}$ at 30 days after inoculation. MS medium supplemented with uniform dose of $5.0 \mu \mathrm{M} \mathrm{BA}$.

\begin{tabular}{lccc}
\hline $\begin{array}{l}\text { Doses } \mathrm{GA}_{3} \\
(\mu \mathrm{M})\end{array}$ & $\begin{array}{c}\text { Shoot number } \\
\text { explant }^{-1}\end{array}$ & $\begin{array}{c}\text { Node number } \\
\text { shoot }^{-1}\end{array}$ & $\begin{array}{c}\text { Node number } \\
\text { explant }^{-1}\end{array}$ \\
\hline 0 & 1.0 & 1.0 & 1.0 \\
2.5 & 1.0 & 1.0 & 1.11 \\
5.0 & 1.44 & 1.11 & 1.41 \\
10 & 1.0 & 1.16 & 1.11 \\
$\mathrm{LSD}_{(0.05)}$ & 0.19 & $\mathrm{NS}$ & 0.25 \\
\hline
\end{tabular}

Table 4. Effect of different doses of ascorbic acid on shoot number explant ${ }^{-1}$, node number shoot ${ }^{-1}$ and node number explant ${ }^{-1}$ at 30 days after inoculation. MS medium supplemented with uniform dose of 5.0 $\mu \mathrm{M}$ BA.

\begin{tabular}{lccc}
\hline $\begin{array}{l}\text { Doses Ascorbic } \\
\text { acid }(\mu \mathrm{M})\end{array}$ & $\begin{array}{c}\text { Shoot number } \\
\text { explant }^{-1}\end{array}$ & $\begin{array}{c}\text { Node number } \\
\text { shoot }^{-1}\end{array}$ & $\begin{array}{c}\text { Node number } \\
\text { explant }^{-1}\end{array}$ \\
\hline 0 & 0.38 & 1.0 & 0.38 \\
282 & 0.50 & 1.16 & 0.58 \\
852 & 1.05 & 1.72 & 1.79 \\
1136 & 0.55 & 0.94 & 0.53 \\
$\operatorname{LSD}_{(0.05)}$ & 0.44 & 0.73 & 0.83 \\
\hline
\end{tabular}

equal value for node number shoot ${ }^{-1}$ at the stage of sampling.

Node number explant ${ }^{-1}$ : Various doses of $\mathrm{GA}_{3}$ significantly influenced node number explant ${ }^{-1}$ at 30 days after inoculation. $5.0 \mu \mathrm{M} \mathrm{GA}_{3}$ significantly enhanced node number explant ${ }^{-1}$ by $41 \%$ in comparison to the control at the stage of sampling.

\section{Experiment 4}

Shoot number explant ${ }^{-1}$ : Effect of different doses of ascorbic acid significantly influenced shoot number explant $^{-1}$ at 30 days after inoculation. $852 \mu \mathrm{M}$ ascorbic acid significantly enhanced shoot number explant ${ }^{-1}$ by $176 \%$ in comparison to the control at the stage of sampling (Table 4).

Node number shoot $^{-1}$ : Use of ascorbic acid significantly influenced node number shoot ${ }^{-1}$ at 30 days after inoculation. $852 \mu \mathrm{M}$ ascorbic acid significantly enhanced node number shoot ${ }^{-1}$ by $72 \%$ in comparison to the control at the stage of sampling.

Node number explant ${ }^{-1}$ : Various doses of ascorbic acid significantly influenced node number explant ${ }^{-1}$ at 30 days after inoculation. Ascorbic acid at $100 \mu \mathrm{M}$ significantly enhanced node number explant ${ }^{-1}$ by $371 \%$ in comparison to the control at the stage of sampling.

\section{Experiment 5}

In vitro adventitious rooting: Various doses of IBA $(0$, 2.5, 5.0 and $10.0 \mu \mathrm{M}$ ) induced significant rooting and root number explant ${ }^{-1}$ at 30 days after inoculation (Table 5).

Adventitious rooting (\%): MS medium supplemented with various doses of IBA significantly enhanced rooting (\%) at 30 days after inoculation. $10.0 \mu \mathrm{M}$ IBA enhanced rooting (\%) by $767 \%$ in comparison to the control and maximum rooting of $72.22 \%$ was obtained on $10.0 \mu \mathrm{M}$ IBA supplemented medium.

Root number explant ${ }^{-1}$ : Various doses of IBA significantly influenced root number explant ${ }^{-1}$ at 30 days after inoculation. 10.0 $\mu \mathrm{M}$ IBA significantly enhanced root number explant ${ }^{-1}$ by $134 \%$ in comparison to the control and maximum root number explant ${ }^{-1}(0.72)$ was obtained on $10.0 \mu \mathrm{M}$ IBA supplemented medium.

\section{DISCUSSION}

The micropropagation of L. glutinosa comprises four steps namely: establishment of culture from nodal explants, shoot multiplication, root induction and harden- 
Table 5. Effect of different doses of IBA on MS medium for in vitro rooting $\%$ and root number explant ${ }^{-1}$ at 30 days after inoculation. Values in the parentheses are arc sine transformation.

\begin{tabular}{lcc}
\hline $\begin{array}{l}\text { Doses } \\
(\mu \mathrm{M}) \text { IBA }\end{array}$ & $\begin{array}{c}\text { Rooting } \\
(\%)\end{array}$ & $\begin{array}{c}\text { Root number } \\
\text { explant }^{-1}\end{array}$ \\
\hline 0 & $8.33(10.97)$ & 0.05 \\
2.5 & $12.49(17.41)$ & 0.11 \\
5.0 & $33.33(35.24)$ & 0.33 \\
10 & $72.22(66.55)$ & 0.72 \\
LSD $_{(0.05)}$ & 14.59 & 0.18 \\
\hline
\end{tabular}

ing and acclimatization. The present investigations pertain to standardization of $\mathrm{BA}, \mathrm{GA}_{3}, \mathrm{IAA}$ and ascorbic acid doses for shoot multiplications and different concentrations of IBA for root induction. The best combination for in vitro shoot multiplication in four experiments emerged to be MS medium supplemented with $5.0 \mu \mathrm{M}$ BA $+852 \mu \mathrm{M}$ ascorbic acid. There is no published report on the in vitro shoot multiplication in the species. BA exhibiting superiority over other sources of cytokinins for differentiation and growth of new shoots is well documented in other species. The possible reason could be that BA is much closely related to natural cytokinins as far as the structures of the latter is concerned.

Amendment of culture medium with ascorbic acid significantly influenced shoot number explant ${ }^{-1}$, node number shoot ${ }^{-1}$ and node number explant ${ }^{-1}$ at the stage of sampling. The increase in shoot number in the presence of ascorbic acid has also been reported in tobacco callus culture (Richard et al., 1988). According to Sharma and Chandel (1992) addition of ascorbic acid to the hormone supplemented medium was essential for bud break and further shoots multiplication. Mechanism of action of ascorbic acid, a common antioxidant/ antibrowning agent, is presently not known. Ascorbic acid or some product of its oxidation may possibly be increasing shoot number through ascorbate protection of endogenous phytohormones as implicated for tobacco, Pinus and Picea (Berlyn and Beck, 1980; Rumary and Thorpe, 1984; Richard et al., 1988). The auxins stimulate root development by inducing root initials that differentiate cells of the young secondary phloem, cambium and pith tissue (Gianfagna, 1995). Roots formed de novo from differentiated cells other than radical are defined as adventitious roots (Casson and Lindsey, 2003). A key stage in adventitious rooting is the de novo formation of root meristem. The in vitro rooting is complex process and is controlled by several factors, major being hormonal and nutritional status of media (Jarvis and Booth, 1981). A successful rooting procedure with high rooting percentage is essential for a competent micropropagation protocol.

In the present study $10 \mu \mathrm{M}$ IBA stimulated adventitious root formation and was found to have significant effect on rooting percentage and root number. IBA is preferred over NAA as it produces strong fibrous root system and is less toxic than NAA (Ahuja, 1991). There are earlier reports by many workers supporting our finding of rooting response with IBA. In medicinal plant species like Gentiana lutea, (Petrova et al., 2011) $1 \mathrm{mg} \mathrm{L}^{-1}$ IBA was found effective for rooting. The best rooting was obtained on MS medium containing $0.5 \mathrm{mg} / \mathrm{I}$ IBA in Solanum nigrum (Kolar et al., 2008). On $3 \mathrm{mg} \mathrm{L}^{-1}$ IBA, rooting was obtained in Chlorophytum borivilianum (Bathoju and Giri, 2012). Maximum number of roots was obtained on 1.5 IBA $\mathrm{mg} \mathrm{L}^{-1}$ IBA in Centella asiatica (Karthtikeyan et al., 2008). $100 \%$ in vitro rooting was obtained when shoot clusters were cultured on MS medium supplemented with $0.15 \mathrm{mg} / \mathrm{L} \mathrm{IBA}$ in Bacopa monnieri (Sharma et al., 2010). IBA has been found effective for rooting of in vitro raised shoots of many tree species also. In Dalbergia sissoo, $1.0 \mathrm{mg} / \mathrm{L}$ of indole butyric acid (IBA) was reported to be the best treatment for rooting (Ali et al., 2012).

\section{Conclusion}

To the best of our knowledge this is the first report on micropropagation of $L$. glutinosa, a critically endangered medicinal tree species. As cultures have been established using nodal segments of mature trees from field, this method will be very useful for cloning of mature trees of this species. The high rooting frequency $(72.2 \%)$ obtained in the present study will help in its propagation in large numbers. The study will also be helpful for ex situ conservation of this endangered species in the form of in vitro cultures.

\section{REFERENCES}

Ahuja MR (1991). Biotechnology in forest trees. Plant Res. Dev. 33:106120.

Ali A, Rizwan M, Majid A, Saleem A, Naveed NH (2012). Effect of media type and explants source on micropropagation of Dalbergia sissoo: A tree of medicinal importance. J. Med. Plants Res. 9:1742-1751.

Bathoju G, Giri A (2012). Production of medicinally important secondary metabolites (stigmasterol andhecogenin) from root cultures of Chlorophytum borivilianum (Safed musli), Recent Res. Sci. Technol. 5:45-48.

Berlyn GP, Beck RC (1980). Tissue culture as a technique for studying meristematic activity. In Control of Shoot Growth in Trees. Proceedings of the Joint Workshop of IUFRO Working Parties in Xylem and Shoot Growth Physiology. pp.305-324.

Casson SA, Lindsey K (2003). Genes and signaling in root development. New Phytol. 158:11-38.

Gianfagna T (1995). Natural and synthetic growth regulators and their use in horticultural and agronomic crops. In Plant Hormones: Physiology, Biochemistry and Molecular Biology, Davies, P.J. (ed.) Kluwer Academic Publishers, Dordrecht. pp.751-773.

Hosamath PV (2011). Evaluation of Antimicrobial activity of Litsea glutinosa, Int. J. Pharm. Appl. 1:105-114.

Jarvis BC, Booth A (1981). Influence of IBA, boron, myoinositol, vitamin $D$ and seedling age on adventitious root development in cuttings of Phaseolus aureus. Physiology Plant. 53:213- 218.

Karthtikeyan K, Chandran C, Kulothungan S (2008) Rapid clonal multi- 
plication through in vitro axillary shoot proliferation of Centella asiatica L. Indian Journal of Biotechnology. 8:232-235.

Kolar AB, Vivekanandan L, Ghouse BM (2008). In vitro regeneration and flower induction on Solanum nigrum $\mathrm{L}$. from pachamalai hills of eastern ghats, Plant Tissue Cult. Biotech. 1:43-48.

Kritikar K, Basu BD (1981). Indian Medicinal Plant, Periodic Book Agency, Delhi, India, III. pp. 2158-2160.

Petrova M, Zayova E, Vitkova A (2011). Effect of silver nitrate on in vitro root formation of Gentiana lutea AC Romanian Biotechnol. Lett. 16:53-58.

Rabena AR (2010). Propagation Techniques of Endangered Sablot (Litsea gultinosa) Lour. C.B. Rob. Nat. Peer Rev. J. 5:56-77.

Reddy KN, Reddy CS (2008). First red list of medicinal plants of Andhra Pradesh, India- Conservation Assessment and Management Planing. Ethnobot. Leafl.12:103-107.
Richard WJ, Patel KR, Thorpe TA (1988). Ascorbic acid enhancement of organogenesis in tobacco callus, Plant Cell, Tiss. Organ Cult. 13:219-228.

Rumary C, Thorpe TA (1984). Plantlet formation in black and white spruce. Canadian J. For. Res. 14:10-16.

Sharma N, Chandel KPS (1992). Effects of ascorbic acid on axillary shoot induction in Tylophora indica (Burm. F.) Merrill. Plant Cell, Tiss. Organ Cult. 29:109-113.

Sharma S, Kamal B, Rathi N, Chauhan S, Jadon V, Vats N, Gehlot A, Arya $S$ (2010). In vitro rapid and mass multiplication of highly valuable medicinal plant Bacopa monnieri (L.) Wettst. Afr. J. Biotechnol. 9:8318-8322. 